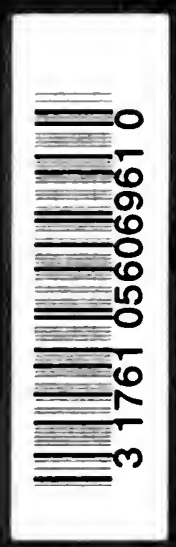




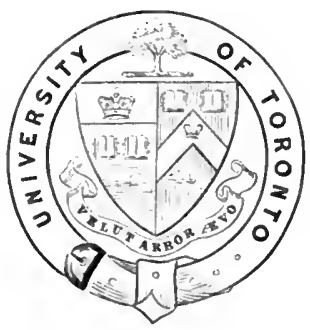

Dresented to

The Tibrary

of tbe

Uniniversity of Toronto

bu

Joseph McCulley, Esq. 
Digitized by the Internet Archive in 2007 with funding from Microsoft Corporation 


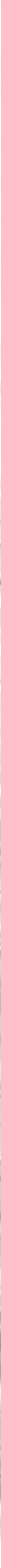




\section{The Ancient East}

Under this title is being issued a series of short, popular, but thoroughly scientific studies, by the leading scholars of Germany, setting forth the recent discoveries and investigations in Babylonian, Assyrian and Egyptian History, Religion, and Archaology, especially as they bear zupon the traditional views of early Eastern History. The German originals have been appearing during the last eighteen months. The English translations made by Miss Jane Hutchison have been submitted in each case to the Authors, and embody their latest vieres. Short, helpful bibliographies are added. Each sindy consists of some 64 to 80 pages, crown 8vo, and custs 1s. sewed, or 1s. 6d. cloth

The following are lssued:

THE REALMS OF THE EGYPTIAN DEAD. By Professor Alfred WiedemanN.

THE TELl EL AMARNA PERIOD. By Dr. C. Niebuhr.

THE BABYLONIAN AND THE HEBREW GENESIS. By Professor H. ZIMMERN.

THE BABYLONIAN CONCEPTION OF HEAVEN AND HEl.L. By Dr. Alfred Jeremias.

POPULAR LITERATURE IN ANCIENT EGYPT. By Professor Alfred Wiedemann. 


\section{The Ancient East \\ $\$$}

No. V

\section{POPULAR LITERATURE IN ANCIENT EGYPT}

A. WIEDEMANN 


\title{
POPULAR LITERATURE IN
}

\section{ANCIENT EGYPT}

\author{
BY \\ A. WIEIDEMANN, PH.D. \\ AUTHOR OF " FGYPTISCHE GESCHICHTE," "HERODOTS \\ ZWEITES BLCH," "DIE RELIGION DER \\ ALTEN AEYPTER," ETC.
}

TRANSLATED BY J. HUTCHISON

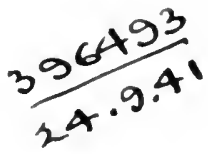

LONDON: DAVID NU'T'T'

57-59 LONG ACRE

1902 


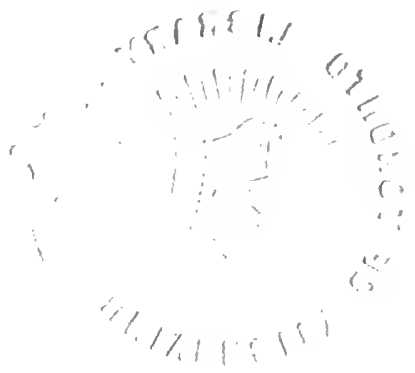




\section{CONTENTS}

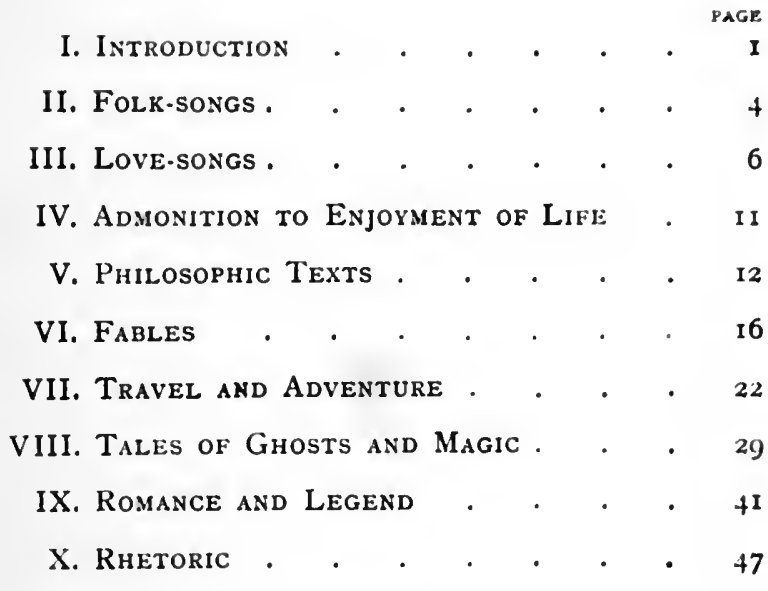





\section{POPULAR LITERATURE IN ANCIENT EGYPT}

For many centuries past and until recently the civilised world was accustomed to regard the ancient Egyptians as a people leading a monotonous and joyless life, unrippled by any passing breeze of ordinary human pleasure, and with minds entirely absorbed in meditations on death or in deep religious and philosophical speculations. It was indebted for this picture in the first place to the allusions made by Greek authors to the wisdom of the Egyptians, while the austerity of Egyptian plastic representations of gods and men, and the vital significance ascribed by this people to all rites and worship connected with the dead, pointed to the same conclusion. This view of the matter was confirmed by the tone of the pompous royal inscriptions and almost exclusively religious texts which were the earliest results of the deciphering of Egyptian writing. Great interest was therefore excited 
when, in I852, Emmanuel de Rougé discovered that a papyrus lent to him in Paris by an English lady (Elizabeth d'Orbiney) contained a story. The new fact met with but tardy recognition in scientific circles, and attempts were made to prove that the subject of the text was not a simple narrative, but a religious myth, retold in a popular form. The legend of Osiris was the original first suggested, but the details of the papyrus showed this to be an unsatisfactory explanation. The next hypothesis was that threads of the traditions prevailing in Asia Minor regarding Atys, Adonis and other divinities had been interwoven with the fabric of the Egyptian myth. This solution likewise proving inadequate, schulars gradually became reconciled to the idea that in the Nile Valley, as elsewhere, men and women had taken delight in romance and song; and before long the discovery of new texts removed every doubt.

In the year I864 a wooden chest was discovered at Thebes, not far from the temple of Deir el Bahari. Besides many Coptic documents, it contained several literary papyri belonging to the later period of ancient Egypt, the most . important of which was a demotic text containing the story of Prince Setna, a tale of magic and enchantment. From this time onward find followed find, and now the variety of such remains 
is so great as to justify the assumption that the secular literature of ancient Egypt may well have been equal in bulk to its religious literature. If in number the works preserved to us scarcely seem to bear out this conclusion, it must be remembered that the principal monuments which still subsist in the Nile Valley are essentially temples and tombs, and that such places were not likely to be used as storchouses for lighter literature. Fairy tales and legends have, indeed, been occasionally discovered in burial-places, but such exceptions may be explained by the Egyptian idea that life after death was as nearly as possible a continuation of life on earth. The occupant of the tomb may well have wished not to be deprived in the next world of the reading which had given him pleasure during his lifetime. Other remains of lighter literature have been unearthed from the dust and rubbish heaps of ancient cities, where they had been cast away in their time as waste papyrus. In such cases they are, of course, much decayed and injured by worms and insects. Lastly, it sometimes occurs that inscriptions on tombs, stelæ, and other monuments reveal traces of this popular literature, though such breaks in the verbose uniformity of official inscriptions are unfortunately but few in number. For the most part we possess mere fragments of these works, very few having been preserved intact. They 
are enough, however, to give us some insight into the romantic side of Egyptian life and thought, and they are in themselves sufficiently interesting to justify us in giving here a brief outline of their contents and significance.

Little or nothing is known of the popular songs of ancient Egypt, though nıodern customs in the East lead us to the conclusion that they were very numerous, and that they were constantly in the mouths of the people. No workman in the Nile Valley to-day sets about any arduous labour without singing, as accompaniment to his toil, a monotonous chant, repeating endlessly the same melody, and, for the most part, the same words also. Things cannot have been otherwise in antiquity, and in this case the almost entire absence of direct evidence admits of easy explanation. As a rule commonplace and everyday matters are not thought worthy to be chronicled, and even in modern times it was long before scholars deigned to give attention to folk songs and stories. The Egyptian scribe, being a great personage, despised the singing of the common people, and did not consider it fitting to transmit to posterity what seemed to him mere doggerel. The few deviations from this rule of silence in the inscriptions have arisen from attempts to portray on the tombs as exactly as possible the incidents of man's life in this world, to which his 
life after death was expected to correspond so closely. Sometimes the utterances of the men at their work, their chat, their exclamations and their songs were added to the pictured or sculptured representations. Often the same text reappears in different tombs, and then we have to do, not with original poems, but with traditionai songs, well known and universally loved.

The herdsman wading in the mud as he drives his sheep over the fields from which the flood has not yet entirely retreated, sings to his flock: "In the water walks your shepherd with the fishes; with the cat-fish talketh he; with the fish he changeth greeting." Another song accompanies the work equivalent to threshing. The ancient Egyptians, like the Israelites, did not use flails, but after scattering the corn on the threshingfloor they drove oxen over it to tread out the grain from the husk. Then was sung with different variations, "Thresh, oh ye oxen! Thresh for yourselves! Oh ye oxen thresh for yourselves! Thresh straw for your fodder, thresh grain for your masters! Take ye no rest, cool is the air this day!"

Slight as are these songs in meaning in this they do but resemble similar poetry in all lands and in all ages. We know nothing of the melodies to which they were sung, but from modern analogies it may unhesitatingly be affirmed that 
they were not particularly varied or artistic, and were probably marked by that wailing cadence at all times distinctive of the music of a poor overburdened peasantry.

More numerous than the folk-songs are the lovesongs handed down to us in Egyptian texts. Later Oriental literature would in itself lead us to the inference that their number must have been great. We need think only of the tales in the "Arabian Nights," where the lover has command of such a fine flow of verses, not to speak of many similar products of Arabian poetry which have come to us from other directions. The Egyptian songs present a parallel to these other Eastern works in the character of the love of which they treat. It is only in exceptional cases a sentimental feeling; as a rule, it is a passion finding for itself intense and realistic utterance. Three collections of lovesongs of about I 200 B.C. have now been discovered. The most comprehensive, containing also legends and tales, is in a papyrus in the British Museum; others are in a papyrus at Turin, and on a potsherd in the museum of Gizeh, the intent of which was first recognised by Spiegelberg. To these must be added a stela in the Louvre, on which the praise of a beautiful woman, a queen of about 700 B.c., is sung as follows :

"The sweet one, sweet in love; the sweet one, sweet in love in the presence of the king; the sweet 
one, sweet in love before all men : the beloved before all women; the king's daughter who is sweet in love. The fairest among women, a maid whose like none has seen. Blacker is her hair than the darkness of night, blacker than the berries of the blackberry bush (?). Harder are her teeth (?) than the flints on the sickle. A wreath of flowers is each of her breasts, close nestling on her arms."

The text unfortunately breaks off here and gives us no further light on the ancient poet's ideal of feminine beauty, a question for the answering of which literary material is wanting. This is the more to be regretted as the plastic representations show that in this respect the taste of the ancient Egyptian was in many points a contrast to that of his modern descendant, recalling rather the conceptions of the Arab of the desert. It is from representations of goddesses and to some extent of queens that such conclusions may be drawn, for in this higher class of work the artist would most probably strive to idealise his models. During the whole classical period of Egyptian history, with few exceptions (such, for example, as the reign of that great innovator, Amenophis IV.), the ideal alike for the male and the female body was a slender and but slightly developed form. Under the Ethiopian rule, and during the Ptolemaic period in Egypt itself, we find for the first time that the goddesses are represented with plump and well-developed outlines. Examination 
of the mummies shows that the earlier ideal was based upon actual facts, and that in ancient Egypt slender, sinewy forms distinguished both men and women. Intermarriage with other races and harem life may have combined in later times to alter the physical type, and with it to change also the ideal of beauty.

A few extracts from the collections will serve to show the nature of the love-songs; their likeness and unlikeness in thought and expression to the poetry of other nations will at once be apparent. The first has a far-off resemblance to the theme of Hero and Leander :

I. "The kisses of my beloved are on the other bank of the river; a branch of the stream floweth between us, a crocodile lurketh on the sand-bank. But I step down into the water and plunge into the flood. My courage is great in the waters, the waves are as solid ground under my feet. Love of her lendeth me strength. Ah! She hath given me a spell for the waters."

2. "When I kiss her, and her lips are open, then need I not ale to inspire me. When the time is come to make ready the couch, oh servant! then say I unto thee: 'Lay fine linen between her limbs, a bed for her of royal linen; give heed to the white embroidered linen, besprinkled with the finest oil." "

3. "Oh! were I but her negress, following her footsteps. Ah! Then should I joy in seeing the forms of all her limbs."

4. "Love to thee filleth my inmost being, as [wine] 
pervadeth water, as fragrance pervadeth resin, as sap mingleth itself [with liquid]. And thou, thou hastenest to see thy beloved as the steed rusheth to the field of battle. Heaven hath formed her love, as the flame taketh hold [on the straw] and [his longing] like unto the hawk as he swoopeth down (?)"

5. "Is not my heart well inclined unto thy love? ... Never shall I be severed from love even though one should beat me ... to Syria with sticks and cudgels, to Nubia with rods of the palm tree, to the mountain land with whips, to the plain with switches. Never will I give ear unto their counsel that I should give up my heart's desire."

6. "I will lay me down in my shelter, sick shall I be with grief. Oh! here come my neighbours to care for me. There cometh my beloved with them; she putteth the physicians to scorn, for she knoweth my malady."

7. "Near the country house of my beloved, where the water tank lieth in the midst of her land, the door openeth, the bolt springeth open, my love is wroth. Oh ! were I made her porter, I should cause her to be wrathful with me. Then, when I did but hear her voice, the voice of her anger, a child should I be for fear."

8. "Thou beautiful one! My heart longeth to make ready the food for thee, as thy house mistress, my arm should rest on thy arm. If thou turnedst away thy caresses then would my heart say within me in my beseeching: 'My dear (friend) is wanting to me this night, and thus am I like one sojourning in the grave.' For art thou not to me health and life? Thy coming filleth with joy in thy prosperity the heart that hath sought thee." 
9. "The voice of the dove is calling; it sayeth : 'The earth is bright, where is my way?' Thou bird, thou art calling to me. But I, I have found my beloved on his couch. My heart is rejoiced above all measure, and each of us sayeth : 'I will not part from thee.' My hand is in thy hand. I walk and am with thee in each beautiful place, thou madest me the first of the fair maidens, thou hast not grieved my heart."

Among the love-songs in the London collection is one which makes a singular impression in such an association, "The song placed in the tombtemple of the departed King Antef, which is written there before the singer with the harp." Thus it runs :

"It is a command of the gracious ruler (i.e., the god Osiris), a good decree, that the (human) body vanisheth in decay, whilst other things endure, remaining from the days of our forefathers. The gods that were aforetime now rest in their tombs; great dignitaries and glorious spirits are likewise buried in their graves. Those who have built for themselves tomb-temples have no abiding-place more. Lo! their deeds what are they (become)? I heard the words of Inshetep and of Horduduf, whose wise words are praised beyond those of others. Where is their place and that which was theirs? Their walls are destroyed, their place standeth no longer, but is as if it had never been. No man cometh thence to portray their form, to describe their surroundings, to move our heart to go to the place whence they departed. Calm thine heart by causing thy heart to bear up 
against it (against the thought of the transitory nature of all that is earthly). Follow thy leeart's desire while still thou remainest (in life)! Pour perfume on thy head; let thy garment be of finest linen, anointed with the true nost wondrous substances among things divine. Do that which is pleasing to thee more than thou didst aforetime; let not thy heart be weary. Follow thy heart's desire and that which is well pleasing in thine eyes. Arrange thine affairs on earth after the will of thy heart, until to thee cometh that day of lamentation on which that god whose heart standeth still (i.e., Osiris) heareth not their wail (of the dying). Weeping obtaineth not the heart (the life) of a man who dwelleth in the grave. On! live out a joyful day; rest not therein. Lo! it hath not been granted to man to take away with him his belongings. Lo! there is none who hath gone hence and returned hither."

A statement of Herodotus, which is repeated by other ancient authors, teaches us the purpose of these words. It was said to be the custom at Egyptian feasts to hand an image of a mummy round the company with the admonition: "Gazing on this, drink and make merry ; when thou comest to die such another must thou be." The thought of death was not intended to sadden, but to stimulate to greater enjoyment of life. Here we have a sharp contrast to the view embodied in the Jewish proverbial writings, especially the socalled "Wisdom of Solomon," where such 
utterances are regarded as a sign of a godless and impious spirit. In many tombs in the Nile Valley texts have been found that repeat the song from the tomb-temple of King Antef, sometimes almost verbally and sometimes in substance, but always dwelling on the thought that life is short and the hereafter uncertain, and that it behoves the children of men to rejoice while they may. The very place in which these exhortations appear sufficiently proves that such a line of thought, far from being considered irreligious, was regarded as the true wisdom, well pleasing to the gods. The Egyptian sought everywhere to look at the happy side of his life on earth, and he succeeded in finding it so entirely pleasant that he could think of nothing better to desire for the next world than to live for ever among the gods much as he lived here below on the banks of the Nile.

The aim of this song is to inculcate a philosophy of life. But the question whether and in what manner life is to be enjoyed was not the only one that occupied the ancient Egyptian. As he brooded over life and its conditions other philosophical problems came within the range of his speculation. Such questions were discussed by the $\mathrm{E}_{3}$ yptians in the form of a dialogue-a form closen for similar purposes in other literatures and even by such a master of pointed style as 
Plato. The matter at issuc is subjected to question and counter-question, sometimes before a large assembly, until at length the correctness of some disputed principle is acknowledged by the side originally opposing it.

A papyrus of the Middle Kingdom (dating about 2500 B.c.), now in the Berlin Muscum, is the most ancient text of this kind that has been preserved in the Nile Valley. The subject is an attempt at the justification of suicide. The speakers are a man and his Khou, his luminous immortal ego, which, according to a well-known Egyptian conception, formed a complete and independent personality, as did also the other various parts of the human soul. Thus, as a man could play draughts with his $\mathrm{Ba}$, talk and exchange gifts with his $\mathrm{Ka}$, so he could find himself at variance and come to agreement with his Khou.

The man who figures in our text is weary of life and has made up his mind to suicide when he is seized with fear as to his future lot, if there should be no one to attend to his burial. In the lost beginning of the dialogue the soul had evidently argued against suicide in general, but the man turns to it with the entreaty that it will perform for him the duties of a kinsman. The soul, however, steadily refuses, pointing out that with death the remembrance of the departed speedily fades away, even the memory of those 
who have erected monuments of granite. It is wise, therefore, for a man to forget his care, and to make the day of his life a happy one. Thus the poor man may live in spite of all the labour and sorrow that fall to his lot.-But the man. will not hearken to this counsel. He loudly bewails his misery, and declares that his name is more utterly contemned than that of the filthiest and most loathsome wretch on earth, and that his brothers and friends have forsaken him. He laments that everywhere on earth the meek are oppressed and the insolent triumph; that dishonesty prevails and the wicked man succeeds; that there are no just men; that none are content. Therefore, he says, does death appear to him in the guise of all that is most pleasing to his soul-the fragrance of myrrh, repose in the cool air, the intoxication of the feast, the fulfilment of the heart's desire.- These long-drawn-out details produce the desired effect. The soul ceases to resist and promises the man that he shall indeed journey to the west, the realm of the dead, and that his limbs shall be laid in the earth. Then, when he at last is at rest, the soul shall descend to him, and together they will prepare for themselves an abiding-place.

A demotic papyrus in the Leyden Museum contains another philosophical text, but its value is diminished by the fact that it was writtcn 
down within the Christian era. It may be assumed that here Greek ideas are found side by side with those of Egypt. Some have even maintained that Christian influences can be detected, but little evidence has been adduced in support of this somewhat improbable theory. The discusion is in the form of a dialogue between a gigantic cat, the representative of the goddess Bast, and a small jackal. The former, speaking from the orthodox standpoint, maintains that this world is ruled and guided by the gods, that good triumphs, and that evil sooner or later meets with due punishment. Retribution nust follow if violence be inflicted on so much as a lamb, for even the mightiest among men cannot drive God forth from his house. The sky may at times be overclouded, the thunder-storm may blot out the light for a moment, morning clouds may veil the sunrise; but, nevertheless, the sun will eventually scatter the darkness and light and joy return with his beams.

In contrast to this spirit of resignation to the gods and to destiny, the jackal paints life from the realistic point of view, maintaining that the right of the stronger prevsils on earth. The lizard devours the insect, the bat the lizard, the snake preys upon the bat and is in its turn preyed upon by the hawk, and thus it goes on throughout the whole scale of creation. It is said, 
indeed, that vengeance must one day overtake the sinner, but no man can see how that may come to pass; no prayer has power to slay an evildoer.

The dialogue is long and varied. Fables are introduced in support of one point or another, and sometimes direct complaints are made against the gods. The bias of the author is in favour of the sceptical jackal, and all his logical acuteness is enlisted on that side. Occasionally the only resource of the cat is to fall into a passion, and the jackal feels a wholesome respect for the very tangible arguments of her claws. The text is, unfortunately, in a bad state of preservation, and the contents, to which Revillout has given special attention, are difficult of interpretation. The little that is intelligible, however, suffices to show that we have here in demotic form one more example of the perpetual antagonism that may be observed in the thought of the most diverse peoples between two views of life-a pessimistic fatalism and an optimism that trusts in the higher powers.

The fable, now as in ancient times a favourite form of literature in the East, flourished, as we have seen, in Egyptian soil. Two small boards in the Turin Museum contain a fable of about I000 в.c., entitled "The Dispute between the Stomach and the Head." This trial is represented as taking place before the supreme 
tribunal of Egypt, the Court of the Thirty, and during the proceedings its president weeps incessantly - a truly Oriental touch. Evidently the stomach first brought forward his plea, but here the text is defective. It gives, however, the answer of the head, who speaks of himself with much detail as the principal beam from which radiate all the other beams that support the house. His is the eye that sces into the far distance, the nose that breathes, the mouth that speaks; he it is that animates all.

We have unfortunately only eight lines of the speech; the rest of the proceedings and the verdict are wanting. The parts preserved, however, enable us to recognise the carliest version so far discovered of the widespread fable of the Strife between the Stomach and the Members. It is well known to most of us as the "Fable of Menenius Agrippa," from the tradition that it was spoken by him to the plebeians on Mons Sacer when, in 492 B.c., they threatened to forsake Rome.

It is so far impossible to say to what extent the animal fable was popular in Egypt. Certainly the statement is often made that the socalled Fables of Esop must have originated in that land of the cult of animals, and in the Leyden demotic papyrus lately mentioned we find the fable of the grateful mouse who freed the 
lion from the meshes of the snare in which he had become entangled. But no conclusive authority in the domain of literary history can be claimed by any a priori "must," and the demotic text, as we have already seen, dates within the Christian era. The fable is in all essentials Greek in conception, and Creek ideas are merely worked out in further detail on their own lines. It is, therefore, more probable that we have in the demotic an adaptation of a Greek text than that the relation is reversed.

Representations of animals engaged in various human employments, such as waging war, playing draughts, performing on musical instruments, are often adduced as evidence of the existence of the animal fable in Egypt. The best known examples of these are found in papyri in London and Turin ; of less importance are a papyrus at Gizeh and several ostraca, all the material alike dating about 1000 B.c. In these pictures, however, there is not a single trait that would compel us to regard them as illustrations of one or more narratives. Lepsius is no doubt correct in his conclusion that their purport is satirical, and that they are intended to caricature the stereotyped monotony of some of the reliefs adorning the walls of tombs and temples. He has succeeded also in placing side by side with the papyrus pictures striking examples of the kind of production of 
which these are parodies. That the pictures were actually intended as parodies is evident from the contents of the section which follows on the animal pictures in the Turin papyrus. The space is filled by erotic caricatures which, as a matter of course, cannot possibly have had any connection with fables. This part of the papyrus is important as being the only example as yet revealed of a specifically erotic literature in the Nile Valley. Such writing was so widespread in the East that its existence in ancient Egypt can hardly be questioned, but no texts devoted to it have so far been discovered.

The only trace of an ethical fable is a fragmentary beginning found in a papyrus of the Ptolemaic period. Its form is worthy of note. The Arabian Nights have familiarised us with the Oriental method of administering indirect reproof to any sultan whose character and deeds appear shocking to those around him. Dread of the royal anger prevents any attempt at direct admonition, so a vizier or other official undertakes to tell a story to the offending monarch, in the hope that he may draw the moral for himself. The Pharaoh who figures in this text is Amasis (died 526 B.c.), the last important ruler of an independent Egypt, and figuring in Herodotus as a roi canaille of popular Greek tradition. He is censured especially for his plcasure-sceking and 
Bacchanalian habits, and we are told how he sought to excuse his occasional excesses by the analogy of the bow which could not always remain tightly strung. The character ascribed to this king in the demotic text is quite in accordance with the Greek tradition:

"It happened one day in the time of King Amasis that the king spake to his nobles :

" "It is my good pleasure to drink Egyptian kelebi' (an extremely intoxicating beverage). They spake 'Oh, our mighty Lord! it is hard to drink Egyptian kelebi.' He said unto them: 'Hath that which I say unto you an evil savour?' They said, ' Oh, our mighty Lord! that which pleaseth the king, that let him do.' The king commanded 'Let Egyptian kelebi be brought to the lake,' and they did according to the word of the king. The king washed himself with his children, and there was no other wine set before them but Egyptian kelebi. The king feasted with his children, he drank much wine for the love which he bore to Egyptian kelebi; then, on the evening of that day, the king fell asleep by the lake, for he had commanded a couch to be placed in an arbour on the shore of the lake.-When the morning dawned the king could not arise because of the heaviness of his carouse. When an hour had passed, and he still could not arise, then the courtier's lamented, saying, - Can such things be? Behold, the king drinketh himself drunken like a man of the people. A man of the people cannot come into the presence of the king on matters of business.' Therefore the courtiers went to the place where the king was lying, and spake: 'Oh! our mighty Lord, what wish doth the 
king cherish?' The king said: 'It is my will and pleasure to make myself drunken. Is there none among you can tell me a story that I may keep myself from slecp?'

"Now, among the courtiers, there was a high official named Peun, who knew many tales. He stood before the king, and began: 'Oh, our mighty Lord! Knoweth the king not the story of the young sailor? In the days of King Psammetichus there was a young sailor and he was wedded. Another sailor fell in love with the wife of the first, and she loved him and he loved her. Then it happened une day that the king summoned him to his presence. When the feast was over great desire took hold upon him -here a hiatus occurs in the text-and he wished once more to come into the presence of the king (?). He returned to his home and washed himself with his wife, but he could not drink as aforetime. When the hour came for bed he could not bring himself to sleep because of the great grief that oppressed him. Then said his wife unto him: "What hath befallen thee on the river?"

The rest is wanting, and we shall unfortunately most probably never know in what particular way the relation of an incident of the reign of $\mathrm{King}$ Psammetichus, also represented by Greek authors as given up to drunkenness, was intended to serve for the edification of King Amasis.

In Egyptian literature, however, texts aiming simply at entertainment are much more numerous than those like the above, having a more or less edifying purport. Most of them share with the 
Arabian Nights the peculiarity that the heroes of the various stories are not fictitious but historical personages. The most illustrious of the Pharaobs and the most distinguished of their generals appear on the scene, and until lately this fact often led investigators into mistaken attempts to find in such papyri trustworthy historical information. That is not possible. The cycle of legends that sprang up in the West round the name of Charles the Great, and the Eastern traditions of Harun al Raschid are not records of actual facts, and this is just as little the case when the stories in Egyptian papyri deal with Kheops, Usertesen, Ramses II., and other kings famed in their day in the Nile Valley. The subordinate characters are sometimes also historical figures, but as a rule they and the more minute details of the stories are alike inventions. The central point of the whole is often an actual incident or an existing fact, such as the taking of a particular town, the existence of a mysterious door, or the remarkable appearance of a statue. The author's part is to elaborate a story accounting for these facts or giving the issue of events connected with them, and here we have no longer history but fiction, invented to give pleasure and to wile away a tedious hour for readers and hearers.

Travel and adventure are the subjects of several papyii. The ancient, like the modern 
Egyptian, was loth to lcave his native field even to travel in other parts of his own Nile Valley. A journey in foreign countries, among strange men, strange gods, and strange tongues, naturally appeared a most formidable undertaking. Nevertheless, it is quite a mistake to imagine the Egyptians entirely cut off from intercourse with other races, dwelling in other states. To satisfy the thirst of Pharaoh for glory or for booty Egyptian soldiers shed their blood on many a distant battleficld; diplomatists left their homes to administer Egypt's foreign possessions, or to carry letters and gifts to the rulers of other empires both far and near. Merchants travelled to buy and sell in unknown regions; slaves and political suspects sought to cross the frontier to escape punishment at the hands of their masters or of the royal court of justice. Self-banishment for the reason last mentioned is still common in the East, and must have been very frequent in antiquity. This is obvious from numerous allusions to fugitive slaves and officials, but above all from a paragraph in a treaty of peace between Ramses II. and his Asiatic neiglubour the Kheta king. Its terms expressly bound each ruler to surrender to the other fugitives and runaway workmen taking refuge in the neighbouring state.

Many dangers attended foreign travel. "The runner, who goes forth into a strange land, 
bequeaths his goods to his children, dreading lions and Asiatics," runs a passage in a description of various occupations preserved in several copies of about 1250 в.c. He who returned safe and sound from such a journey was regarded at home as a hero. His friends and neighbours hastened, just as they would to-day, to hear his account of his adventures. Like the modern teller of " travellers' tales," he was no punctilious stickler for exact truth. Many an incident probably received a more attractive colouring, while many others were clearly invented to give the traveller grcater importance in the eyes of his friends and fellow countrymen. Thus, side by side with the simple tale of travel narrating with fair correctness possible events, there was developed in ancient Egypt the tale of marvellous adventure, reminding us in its fantastic adornments of the adventures of Sinbad the Sailor or of Lucian's True Histories.

In the story of Saneha (Sinuhit) we have the earliest known example of a tale of travel which avoids impossibilities and simply narrates facts. It originated during the Middle Kingdom, but was still copied and read more than a thousand years later. No mention of the hero has been found in inscriptions, so that it cannot be decided whether he was a real or a fictitious character. His name Saneha ("son of the sycamore- 
goddess") occurs not infrequently during the Middle Kingdom and at the beginning of the New Kingdom. Our Sancha was an important dignitary under the first king of the Twelfth Dynasty, Amenemhat I. On the death of this Pharaoh and the accession of his son, Usertesen I., Sancha happened to witness an embassy received by the king which was intended to be kept strictly sccret. Fcaring to be called to account for his knowledge of a state secret, he resolved to make his escape, and hid himself till the king had left the spot. He fled eastward across the flats of the Delta, and slipped past the fronticr wall, called "The Wall of the Ruler," which here formed the boundary of Egypt, and sccured the fertile levels of the northern Nile Valley against the raids of the nomadic tribes that swarmed in southern Palestine and in the Sinaitic Peninsula. Sancha journeyed from the Wall to the Bitter Lakes, and herc, on the desolate steppe, he was overpowered by thirst; his throat was parched, and he said, "This is the taste of death." After a brief rest, he plucked up heart, and presently the distant lowing of cattlc prepared him for the approach of a Bedawi. The man treated him kindly, gave him water, boiled milk for him, and offered him a home with his tribe. But Sancha. felt hinself unsafe so near to the Egyptian frontier, and therefore went on his way as far as the Upper 
Tenu, a district probably to be sought in the south of Palestine. Here he married the eldest daughter of the chief, and dwelt in the land for many years, rich, happy, and respected. But a longing for home took hold upon him as he grew older, and the matter was laid before King Usertesen who granted him permission to return. He was kindly received at court, Egyptian garments were given to him, and a royal command was issued to build for him a magnificent tomb-the greatest honour in the power of the Pharaoh to bestow. Most vivid descriptions of the land of the Bedawin, their perpetual feuds and other details of their life, are interwoven with the narrative, which has thus a special interest as the earliest known contribution to the history of the civilisation of the Palestinian nomads. Side by side with these idyllic pictures stand crude and wordy eulogies of the monarch in the Nile Valley. These were probably congenial enough to the Egyptian reader, but judged by the standard of modern taste, they form mere interruptions, tedious and irritating, of the simple story of Saneha.

The story of the Shipwrecked Sailor belongs to about the same period as the story of Saneha, but exists only in one papyrus copy now in St. Petersburg. Like the tale of Saneha, this also is told in the first person, the hero being supposed to relate his own adventures; but, unlike 
the former, it neither names the liero nor gives any details of his previous life.

The narrator had set sail for the royal mines; a storm arose and the ship went down with all hands. He alone succeeded in seizing a plank and by its aid kept his head above water. For three days he was swept onward by a great wave, which at length cast him upon an island, where he found food and offered a burnt offering to the gods. Hearing a terrible noise which caused the trees to quiver and the earth to tremble, he looked round and saw approaching him a gigantic snake, thirty ells long, with a beard measuring two ells. Its limbs were inlaid with gold, and its colour was that of lapis lazuli. This creature seized the sailor, carried him to its home and ordered him to tell how he had come to the island. After listening attentively to his tale, the monster explained that he had been cast away on the island of the Ka (i.e., the soul), the home of the snake and of its brothers and children, seventy-five in all. There dwelt also among then: a maiden (probably to be regarded as human), whom chance (?) had brought to their midst. The snake predicted that the sailor should sojourn on the island for four months, and should then be rescued by a passing ship. As a matter of course, this prophecy was fulfilled. When the appointed time had come, the sailor received rich gifts of 
frankincense, jewels, ivory, dogs, apes and other precious things. These were taken on board the ship and the rescued mariner sailed through Nubia, down the Nile to the residence of the Pharaoh.

Later by more than a millennium than the adventures of Saneha and of the shipwrecked sailor, is a description, dating about 1250 B c., of a journey through Palestine and Phoenicia, preserved in a London papyrus and in the fragments of two other copies. The aim of this story is not to describe the journey itself, though a list is given of the towns visited and individual adventures are narrated. Its intention is rather, by means of a story of an imaginary journey, to satirise the absurdities and the artificial style popular at that time in such descriptions. The story is of great value for another reason besides its noteworthy position as an carly piece of literary history. It depicts most vividly the insecurity prevailing in the south of Syria as far as Egypt, at the end of the second millennium, B.c.; that is, about the time of the conquest of Canaan by the Jews. Although the country had been again and again under the suzerainty of Egypt, and had been strongly influenced by Babylonian-Assyrian civilisation, yet the text shows that a journey through it was still a matter of great difficulty and no small danger. 
The wondrous adventures related by the shipwrecked sailor to his fellow countrymen would not by any means be so astounding to them as to a modern audience. The ancient Egyptian believed that even in the Nile Valley there was no lack of ghostly and magic agencies ready at any moment to interfere in his life, quite irrespective of his good or evil deserts. A papyrus of the Middle Kingdom tells how a herdsman espied the spectre of a woman in a lake. Beside himself with terror he urged the other men to depart as speedily as possible from the spot. This necessitated the driving of the cattle through the water, and meanwhile those of the herdsmen who were expert in magic were told off to repeat the spells intended to secure cattle against any of the dangers of water, especially against crocodiles. The men did so, but when the procession was in motion the spectre, having torn off her garments and dishevelled her hair, appeared once more to the first herdsman. The conclusion of the story is unfortunately missing, so we know not whether the man escaped or fell a victim to the ghost.

In another later text, parts of which are written on ostraca now in Paris, Vienna and Florence, Khunsu-cm-heb, the hero, who was high priest of the god Amon, is anxious to make arrangements for his tomb. The operations of his workmen apparently disturbed an earlier vault, and the nummies 
whose resting-place had been desecrated, began to converse with him and to tell him, though in phrases difficult to be understood, the stories of their lives. The remains so far discovered are not sufficient to give the connection of the narrative, but fragments evidently written by different hands show that they were used about 1000 B.C. as copies for the practice of writing, and must at that time have been part of the more popular reading of the Egyptian people.

The so-called Westcar papyrus, in the Berlin museum, must be considered side by side with these brief fragments of ghost stories. It was written about I 800 B.c., at the beginning of the New Kingdom, evidently from more ancient originals, and is devoted chiefly to tales of magic and enchantment. Beginning and end are wanting as in so many Egyptian papyri, yet enough of the matter has escaped destruction to enable us to form a fairly correct idea of the text as a whole. The papyrus tells how Kheops-the king whom notices of Greek writers have made universally famous as the builder of the Great Pyramid of Gizeh-commands stories of magic to be told to him. The first of these, of which the conclusion only remains, is supposed to have occurred in the reign of King 'T'eser of the Third Dynasty. The next, which is complete, belongs to the reign of Nebka, a somewhąt eạrlier king. 
In those days it came to the ears of a great nobleman that his faithless wife was in the habit of meeting her lover by the side of a lake. Being skilled in magic he modelled a crocodile in wax and ordered one of his servants to cast it into the water. It was immediately transformed into a real crocodile and devoured the lover. Seven days later the king was walking by the lake with his friend the nobleman, when at the command of the latter the crocodile came to the shore and laid its victim at their feet. The king shuddered at the sight of the monster, but at the touch of its maker it became once more a mere figure of wax. Then the whole astonishing story was told to the king, who thereupon granted the crocodile permission to take away that which was its own. The creature plunged into the depths of the lake and disappeared with the adulterer, while the guilty wife was burnt to death and her ashes were scattered in the stream.

A tale of enchantment follows, the scene of which is laid during the reign of King Sneferu, the predecessor of Kheops. This king was one day taking his pleasure on a lake in a boat rowed by twenty beautiful maidens, when one of the girls dropped a malachite ornament into the water. The king promised to give her another in its stead, but this did not content her, for she wanted her own jewel and no other. A magician was 
summoned who repeated a spell by the might of which he piled one half of the lake on the top of the other, so that the water, which at first was twelve ells deep in the middle of the lake, now stood twenty-four ells high. The jewel, found lying in the mud in the dry portion of the lake, was restored to its owner; and the magician having once more mumbled his spell the water returned to its former place.

When Kheops had listened for some time with much interest to the accounts of the strange events that had transpired in the days of his predecessors, then stepped forward Prince Horduduf, who is already known to us from the song in the tomb-temple of King Antef as renowned for his wisdom. He told the king that all marvels were not things of the past, but that even then there was living a magician named Deda, who was one hundred and ten years old, and consumed every day five hundred loaves, a side of beef, and a hundred jars of beer. Kheops was so much interested that he sent the prince to escort the magician to his presence. Deda obeyed the royal summons and performed his chief feat before the king. This consisted in decapitating a goose, a duck, and an ox, and charming the heads back again on to the bodies so that the creatures lived and breathed as before. Kheops fell into talk with the magician, who told him that the wife of 
a priest in Sakhebu was awaiting the birth of three sons, children of the god Ra, who should one day sit on the throne of Egypt. Deda sought to allay the king's natural distress at this information by prophesying that only after the reigns of his son and grandson should the power fall into the hands of the descendants of the Sun-god. But Kheops was not to be so consoled; he inquired into the details of the story and announced that he would himself travel to Sakhebu, no doubt with the ultimate intention of finding an opportunity to put out of the way the pretenders to his throne.

The scene of the sequel is laid in Sakhebu. The birth and infancy of the three children are described in detail, and all sorts of marvellous incidents are represented as influencing their fate. The gods cared for the safety of the little ones. A maid to whom the secret was known being enraged by a severe punishment inflicted upon her, threatened to betray all to Kheops. Her own brother beat her, and when she went down to the water she was carried off by a crocodile.Here the papyrus ccases, but it is possible to a certain extent to restore the conclusion. The names of the three children of Râ show that they stand for the first three kings of the Fifth Dynasty, the family that followed the house of Kheops. The papyrus must therefore have told how the 
boys escaped all the snares laid for their lives and in due time ascended the throne for which they were destined. One historical blunder, however, is evident in the text. According to this only two descendants of Kheops reigned after him before the rise of the new dynasty, but the lists handed down from antiquity indicate at least four rulers during the interim.

In the papyrus just described marvellous incidents are brought into connection with the names of those rulers who played a leading part in the golden age of Egyptian history-the period of the builders of the pyramids. Historical personages of later times are treated in a similar way. The London papyrus, from which the love songs were extracted, couples a story with the name of Thutia, a man well known from numerous monuments and inscriptions as one of the generals of Thutmosis III., the most warlike monarch of the New Kingdom. The papyrus relates his success in retaking the city of Joppa, which had rebelled against Pharaoh. Having laid his plans in concert with his king, Thutia marched against Joppa. He took with him a band of picked men, five hundred large jars, and the king's great cane. Arriving before the town, he represented himself as a traitor to the Egyptian cause. The prince of Joppa, delighted at the prospect of winning over such an important official 
hastened to meet him, kissed him, took him to his resting-place, and ate and drank with him. As he expressed a wish to see the great cane of Pharaoh, Thutia sent for it, held it before him as if for his close inspection, and suddenly gave him such a violent blow on the head that he fell down unconscious. Then Thutia commanded two hundred of his men to conceal themselves in two hundred of the jars, and ordered the remaining jars to be filled with cords and fetters. The rest of the army marched up to the walls carrying the jars, and told the inhabitants that Thutia had been taken prisoner, and that they were now bringing him in with his men and his goods in the jars. The people of Joppa were deceived and admitted the bearers of the jars. The bearers thereupon released their comrades and with their help seized the city.-At the first glance we are struck by the resemblance between this tale and such incidents as that of the wooden horse which caused the fall of Troy, or of the oil-jars in the tale of Ali Baba and the Forty Thieves. In the Egyptian tale a peculiar feature is the somewhat indefinite magic power ascribed to Pharaoh's cane. It is owing to its influence that the prince of Joppa is so heedless in exposing himself to danger, and that the citizens fail to see through Thutia's somewhat transparent fiction. 
Greek authors, writing on Egyptian antiquity, allude often and in many different connections to legends, the essential interest of which centres in one or more marvellous incidents, and thus they bear witness to the number and variety of such tales in the Nile Valley. It is seldom possible from these allusions to come to any conclusion as to the date of the tales in question. Many may have originated as late as the Greek period, for such literature was extremely popular at that particular stage of Egyptain development. Three voluminous stories of enchantment have already been published from demotic papyri of the Ptolemaic period and of the first decades of the Roman supremacy. Many other works of the same kind will probably be brought to light as the result of more thorough working over of the existing material.

One of the texts already accessible claims to narrate historical facts and dates about the middle of the eighth century B.c. Its subject is the strife for a mysterious coat of mail belonging originally to Heliopolis, but taken away before the story opens by the officer in authority over the Mendesian Nome. The chiefs of many of the divisions of Lower Egypt assembled by the Lake of the Gazelle, in the presence of Petubastis, the reigning Pharaoh. Some desired to win back the coat of mail for Heliopolis; the 
others, with whom Pharaoh was in sympathy, tried to secure it for its present possessor. It was essentially a struggle between the princes of the northern and southern Nomes of the western and central Delta, and in the end the king saw himself forced to give up the armour to the rightful owner. The papyrus is fragmentary, and this is a regrettable loss to political no less than to literary history. As far as the scanty documentary records of Egypt and Assyria allow us to come to any conclusions, the picture drawn by this papyrus of the confused internal conditions in the Nile Valley during the eighth century B.C. is absolutely correct. It was the period shortly before the invasion of the Ethiopians and the breakdown of the native dynasty, weakened as it now was by the gradually increasing power of the princes of the Nomes. The accuracy of the historical setting indicates that the germ at least of the story is of much earlier date than the copy now in Vienna.

Both the other papyri treat of the personality and the family of Prince Setna Khâ-em-ust (Satni Khamöis), a son of Ramses II., who, according to the inscriptions, devoted his life chiefly to religious ceremonies. For some years he was heir-apparent to the Egyptian throne, but died before his father, and was probably buried in one of the Apis vaults in the Serapeum at Memphis. 
Egyptian tradition soon connected his name with the practice of magic, and a spell for conjuring demons was said to have been found by him under the head of a mummy in the necropolis of Memphis. The first text, which has been known to us since 1867 , tells that this prince, being skilled and zealous in the practice of necromancy, was one day exhibiting his acquirements to the learned men of the court, when an old man told him of a magic book containing two spells written by the hand of Thoth himself, the god of wisdom. He who repeated the first spell bewitched thereby heaven and earth and the realm of night, the mountains and the depth of the sea; he knew the fowls of the air and every creeping thing; he saw the fishes, for a divine power brought them up out of the depth. He who read the second spell should have power to resume his earthly shape, even though he dwelt in the grave; to see the sun rising in the sky with all the gods and the moon in the form wherein she displays herself. Setna inquired where this book was to be found, and learned that it was lying in the tomb of Nefer-ka-Ptah, a son of King Mer-nebptah (who is nowhere else named), and that any attempt to take away the book would certainly meet with obstinate resistance. These difficulties did not withhold Setna from the adventure. He entered the tomb of Nefer-ka-Ptah, where he 
found not only the dead man, but the $\mathrm{Ka}$ of his wife Ahuri and their son, though these latter had been buried in Koptos. Ahuri told all the trouble that the possession of the book had brought upon her husband and herself, but her tale of woe produced no effect upon the intruder. Setna persisted in his undertaking, and at length, by the help of magic, he gained his end. But as in many other tales among many other peoples, success brought no blessing to the man who had disturbed the repose of the dead. Setna fell in love with the daughter of a priest at Memphis, who turned out to be a witch, and took advantage of his intimate connection with her to bring him to ignominy and wretchedness. At length the prince recognised and repented of the sacrilege he had committed in carrying off the book, and brought it back to Nefer-ka-Ptal.. In the hope of atoning to some extent for his sin he journeyed to Koptos, and finding the graves of the wife and child of Nefer-ka-Ptah, he solemnly restored their mummies to the tomb of the husband and father, carefully closing the tomb he had so sacrilegiously disturbed.-The second text, edited two years ago by Griffith from a London papyrus, is also genuinely Egyptian in its details. Three magic tales, interwoven one with another, are brought into connection with Saosiri, the supernaturally born son of Setna. In the first, Saosiri, who was 
greatly Setna's superior in the arts of magic, led his father down into the underworld. They penetrated into the judgment-hall of Osiris, where the sights they saw convinced Setna that a glorious future awaited the poor man who should cleave to righteousness, while he who led an evil life on earth, though rich and powerful, must expect a terrible doom. Saosiri next suceeeded in saving his father, and with him all Egypt, from great difficulty by reading without breaking the seal a closed letter brought by an Ethiopian magician, whom he thus forced to recognise the superior power of Egypt. The last part of the text tells of a powerful magician once dwelling in Ethiopia who modelled in wax a litter with four bearers to whom he gave life. He sent them to Egypt, and at his command they sought out Pharaoh in his palace, carried him off to Ethiopia, and, after giving him five hundred blows with a cudgel, conveyed him during the same night back to Memphis. Next morning the king displayed the weals on his back to his courtiers, one of whom, Horus by name, was sufficiently skilled in the use of amulets to ward off by their means any immediate repetition of the outrage. Horus then set forth to bring from Hermopolis the all-powerful magic book of the god Thoth, and by its aid he succeeded in treating the Ethiopian king as the Ethiopian sorcerer had 
treated Pharaoh. The forcign magician then hastened to Egypt to engage in a contest with Horus in magic tricks. His skill was shown to be inferior, and in the end he and his mother received permission to return to Ethiopia under a solemn promise not to set foot on Egyptian territory for a space of fifteen hundred years.

Besides such tales of magic, other legends of diverse character gathered round the personality of the earlier Pharaohs, and at a later cpoch these formed the principal source of the statements of classical authors regarding the ancient history of Egypt. These authors, of whom Herodotus is the most important, were entirely wanting in the knowledge of the Egyptian language and writing necessary for the verification of actual events, and such they do not relate. They repeat, not facts, but the tales their fellow countrymen, settled for centuries in Egypt, could tell them of the origin and purpose of ancient buildings or of the life of this or that historic personage. These Greek settlers, again, owed their knowledge not to first-hand investigation, but to mere hearsay. Their intercourse with their Egyptian neighbours was limited to the traders, merchants and guides with whom their business brought them into contact, and from whom they would hear only the legends current among the people. Before the Ptolemaic period the Greeks had little or no 
contact with priests, scholars, and other more cultivated Egyptians, who had a certain amount of exact knowledge of the history of their own land. The strong hatred of foreigners which had by this time developed among the upper classes must have kept the two elements of the population permanently apart. Herodotus and his compeers retold the popular legends and sought thus to produce a homogeneous picture of the development of the Egyptian people. The task was naturally beyond their powers, and their works have therefore but small value as history, though the fact that they have preserved many legends not mentioned in any papyri as yet discovered gives them great importance from another point of view. Even the Egyptian priest and historian, Manetho, who in 270 B.c. wrote a history of Egypt in Greek, could not entirely free himself from legend and tradition. He worked under much more favourable conditions than did Herodotus, and was able to use as the basis of his history a trustworthy list of Pharaohs. But when he came to treat of the deeds of individual rulers his authorities were, not the monuments themselves, but the legends connected by the papyri with the names inscribed on them.

Strong testimuny to the exactness with which the Greeks followed their models is found in the tale of the rich King Rhampsinitus and the dis- 
honest sons of his chief builder. The narrative is so faithful even in detail to the customs of the country that the author, or perhaps rather his authority, must have rendered his original in Greek as nearly as possible word for word. Besides such legends as have been preserved entire in classical works, numerous references occur from which the existence, if not the details, of other similar stories may be inferred. To this class belong various allusions made to the journey of Rhampsinitus in the underworld; to the shepherd Philitis, after whom the pyramids are said to have been named; to King Sesonkhosis, who was five ells high; and others of a similar kind.

Legends written down by the ancient Egyptians themselves must be added to those recorded by the Greeks. A papyrus of about 1250 B.C. contains the beginning of one of these, dealing with the war against the Hyksos. These Asiatic invaders conquered the Egyptians, and oppressed them for centuries, until about 1800 B.c. the people rebelled against the foreign yoke. The papyrus evidently described an encounter between the rival potentates: Apepi, the Hyksos of Avaris, and the leader of the national party, Rà-sekenen (Soknunri), whose dwelling-place was in Upper Egypt. Each propounded to the other riddles and difficult problems, on the solution of which the fate of his adversary was to depend. 
The Greek conquest and the consequent loss of independence did not quench in the Egyptians the love of legend and romance. Various prophecies relating to events in the national history, ostensibly ancient in date, are found in demotic papyri. The fragment now in Vienna of a text written in the reign of Augustus, contains scraps of the divinations of a lamb, supposed to have been uttered about 720 B.C., in the time of Bokkhoris, a monarch renowned in legend. A Greek papyrus of the Ptolemaic period gives the beginning of a story of Nectanebus, the last independent native king, and seems to tell of his expulsion from the throne. About the same time also the Greek cities on the banks of the Nile saw the beginning of the great cycle of romance that gathered around the name of Alexander. In this the birth and exploits of the Macedonian conqueror were narrated with every possible legendary adornment, and for centuries, in various phases, it formed a most important element in the literature of East and West alike. A fragmentary text in Coptic shows that the deeds of the Persian king Kambyses were glorified in a similar fashion, and this was the case with the exploits of many other heroes also. Thus, side by side with the true records of the country, we find romantic and legendary tradition, so widespread and popular that it occasionally entirely superseded authentic 
history. Modern investigation has often great difficulty in restoring the truth to its rights, and success in this endeavour has certainly the disadvantage of making the course of Egyptian history appear much less vivid and poetic than when seen in the garb of romance with which the ancient Egyptians themselves delighted to invest it for the eyes of posterity.

It was not often that the writers of these stories could resist the inclination to identify their hero with one or other of the great figures of the historic past, and seldom did they equip him with an entirely fictitious name, or leave him namcless. The first is the case in the Story of the Two Brothers, contained in the d'Orbiney papyrus, mentioned in the beginning of this little work. Its hero, the herd and husbandman Batau, lived with his brother Anepu, and helped him with the work of his farm. The wife of Anepu charged Batau with an attempt at adultery; the husband believed his wife's tale, and threatened his brother's life. Batau succeeded in escaping, and took refuge in a lonely ravine among the mountains, where he lived by hunting. The gods created a wife to cheer his solitude; but she proved false, and became the beloved of Pharaoh. The brother, who had in the meantime discovered his error and slain his guilty wife, set forth to seek for Batau. He succeeded in finding him, and 
the two brothers travelled to the court that Batau's treacherous wife might be called to account. In spite of many complications and difficulties, Batau attained his purpose, and became in the end king of Egypt, appointing his brother his chief functionary and successor. The first part of this story gives a clear and true picture of Egyptian country life, while the second is full of marvels and prodigies, a genuine piece of oriental phantasy. It is noteworthy that the heroes are entirely fictitious characters, and that the king who plays a part in the story is not named, but introduced simply as Pharaoh, i.e., "Great House," the universal title of Egyptian monarchs.

The story of the Doomed Prince, which belongs to the second millennium B.c., has for its hero the unnamed son of an unnamed king. At the birth of the child the seven Hathors, who play the part of our fairies, prophesied that he should meet his death by means of a crocodile, a serpent, or a dog. His father at first took most elaborate measures to secure him from these dangers, but as soon as he had grown to manhood he set out in search of adventures, accompanied by a dog. By a remarkable feat he won the hand of the daughter of the prince of Naharina, a province on the borders of Syria. Soon after the marriage the vigilance of his wife saved him from a serpent, and a crocodile lurking 
in the river was closely watched by a giant whose duty it was to guard the prince from injury. The creature managed to evade his watchfulness and attacked the prince, but the giant hastened in pursuit and came to the rescue in time. No doubt the faithful dog turned out to be the innocent instrument of doom, but the sudden cessation of the text leaves the catastrophe uncertain.

In discussing the story of Saneha attention was drawn to the long-winded eulogies of the king, which appear to our literary taste so intrusive. Ancient Egyptian authors took pleasure in the multitude of such phrases, and rhetoric is lord of all especially in hymns to gods and kings, where commonplace poverty of thought is often concealed by a pompous diction. The best evidence that similar tendencies came to prevail in the lighter literature also is found in the so-called Story of the Peasant. It dates from the Middle Kingdom, and must have been extremely popular in antiquity, as the remains of at least three copies have been handed down through millenniums to our own day.

The actual narrative is simplicity itself. A peasant who had gone out to get natron and salt was returning with well-laden asses to Heracleopolis Magna, in Upper Egypt. As he approached a narrow part of the road, with the river on ous 
side and standing corn on the other, he attracted the notice of a servant of the High Steward Meruitensa. This man coveted the asses and their load, and said within himself: "The time is favourable unto me; I will rob for myself the goods of this peasant." To make a pretext for an angry dispute he laid down a piece of cloth on the narrowest part of the way and shouted to the peasant that he must take good care not to tread upon it. In the effort to avoid the cloth the peasant drove too near to the corn and one of his asses took advantage of the opportunity to munch a mouthful in passing. Thereupon the owner of the grain feigned to fly into a violent passion, and taking the asses from the peasant he drove them on to his own land. The peasant raised his voice in loud lamentation, but the only result was that a beating was added to his otl.er injuries. The whole day long he ceased not to wail and bemoan himself, but his property was not restored to him, and he departed to Heracleopolis to lay his case before Meruitensa. This potentate left the decision to his counsellors, who, with but little delay for examination into the facts, pronounced against the peasant. He, nowever, did not accept this award as final, but in highly poetic phraseology besought the aid of the Lord High Steward himself. Astonished and delighted by this display of eloquence Meruitensa 
felt moved to tell King Ra-neb-ka-n of the wonderful peasant orator whom he had discovered. This remarkable phenomenon interested the king, and he gave orders that the lawsuit should be dragged out to as great a length as possible, and that all the speeches made in the course of it by the peasant should be written down. While this was going on the peasant and his wife and children were to receive a plentiful allowance of food, but the source of the supplies was to be kept a secret from them. The king's orders were obeyed, and yet eight times the peasant pleaded his cause, lamenting his hard fate in ever more and more touching language, till at length he lost heart and threatened to put an end to himself. Then Meruitensa's compassion was aroused, and he ordered all the orations to be collected in one great papyrus roll. This was presented to Pharaoh, who took more delight therein than in aught else in his whole land. The kinsmen and property of the peasant were brought upon the scene, and at last he received the long-delayed justice.

In this story the nine orations formed the most important element in the eyes of the author, as well as of the ancient Egyptian reader. In elaborate phrases, continually increasing in exuberance, the peasant eulogised the Lord High Steward, and held before him the prospect of the highest honours as a reward for a righteous 
judgment. Occasionally the sentiments expressed would not be out of place to-day; as, for example, the statement that truth endures for ever and follows the upright man to his tomb. His name is not blotted out when his body is buried, but the record of his righteousness lives on amongst men. Again a modern note is struck when it is said of Meruitensa that he is the father of the poor, the husband of the widow, the brother of the outcast. But however pleasing it may have been to the ancient Egyptians to hear the Lord High Steward spoken of as the apron that covers nakedness, the fire that cooks the raw flesh, the rudder that steers the heavens, or the beam that supports the earth, to us these similes appear no less strange than the very peculiar method of conducting a lawsuit. The authorities withhold justice from an injured man until, in his despair, he is ready to put an end to his own life and carry his plea into the next world-and all this simply to call forth from him certain feats of rhetoric. A similar conception of the duty of the rich towards the poor and oppressed runs through the tales in the "Arabian Nights." There, also, the peasant is expected to be grateful for the comparative mildness of his treatment at the hands of those in power if, after anxious and weary waiting, he is at length restored to the possession of property legally 
his own, of which he has been wrongfully deprived.

Enough has now been adduced to show that the anciert Egyptians were active in practically all the departments into which we are accustomed to divide our lighter literature. It is, surely, no slight evidence of their success that many of these works, though their details here and there strike us as remote, have considerable interest for the men and women of to-day. The stories and poems serve also to testify that the ancient Egyptian was no stiff simulacrum of humanity, leading the joyless and monotonous existence that later centuries conceived to become such an entity. He was, on the contrary, a genuine human being of ordinary flesh and blood; his interests, his feelings, his longings, and his sufferings were such as he and we share with all our brethren of mankind. Those long past ages have left many traces behind them in the life of the modern East. It is not alone the huts and the goods and chattels of the peasants that have remained unaltered in the course of five or six millenniums. In the conservative soil of the Nile Valley the life of thought and feeling also has undergone but little change during the long process of the ages. 


\section{BIBLIOGRAPHICAL APPENDIX.}

THE bulk of the known Egyptian Tales have been collected for popular reading by Prof. G. MASPÉRO, in his Contes populaires de l'Egypte Ancienne, 2nd ed. I899 (with full bibliography), and by Prof. Flinders PETRIE, in his Egyptian Tales, Ist and 2nd series, 1893-5. The love-songs are all elaborately edited by W. MAX MüLLER, in Die Liebespoesie der alten Agypter, I899, and "The Dialogue of the despairing Man with his Soul " is described by Erman, "Aus den Papyrus der Königlichen Museen zu Berlin." For "The Dispute of the Stomach with the Head" the reader may be referred to MASPÉRo, Etudes Egyptiennes, i. p. 260 et seq.; for the caricatures to Lepsius, AUswahl, TAFEL, 23, Turin and London, and BRugsch, Agyptische Zeitschrift, pp. 35, 140 seq., Gizeh ; for "The Prophecies of the Lamb," to KraLL, Vom König Bokchoris, Innsbrïck, I898.

Few of the texts in demotic have as yet been translated with any approach to accuracy. KRALL has edited the "War of the Coat of Mail" in Ein Neuer Historischer Roman in demotischer Schrift, Vienna, 1897, and GRIFFITH, the "Stories of Sethon (or Setne) Khamuas," in Stories of the High Priests of Memphis, 1900. 


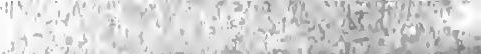

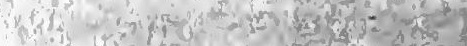

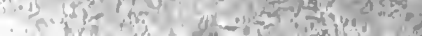

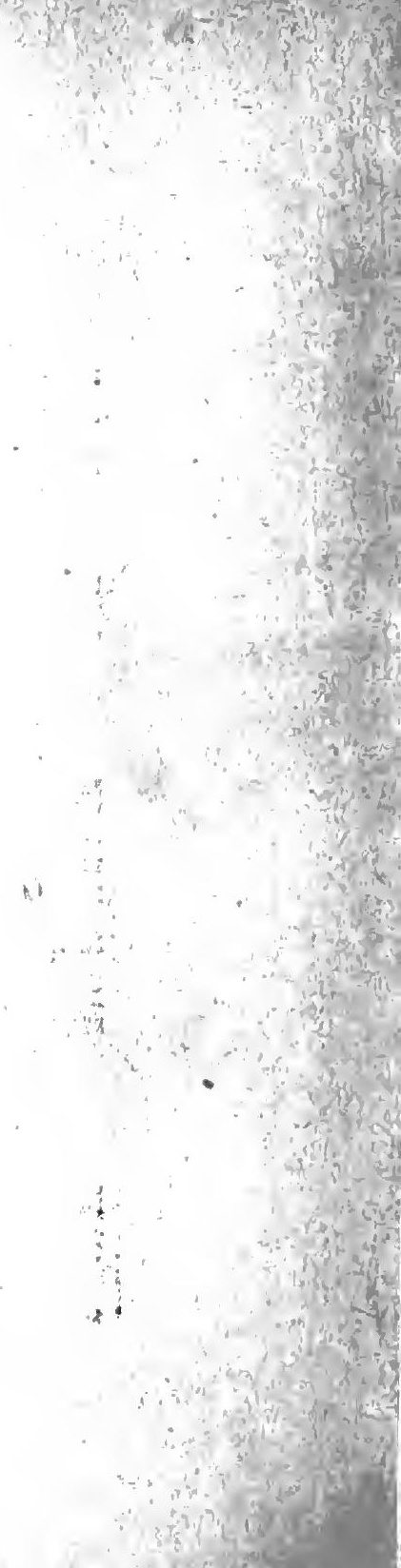

$x_{-1}^{4}$

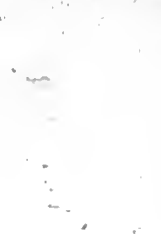




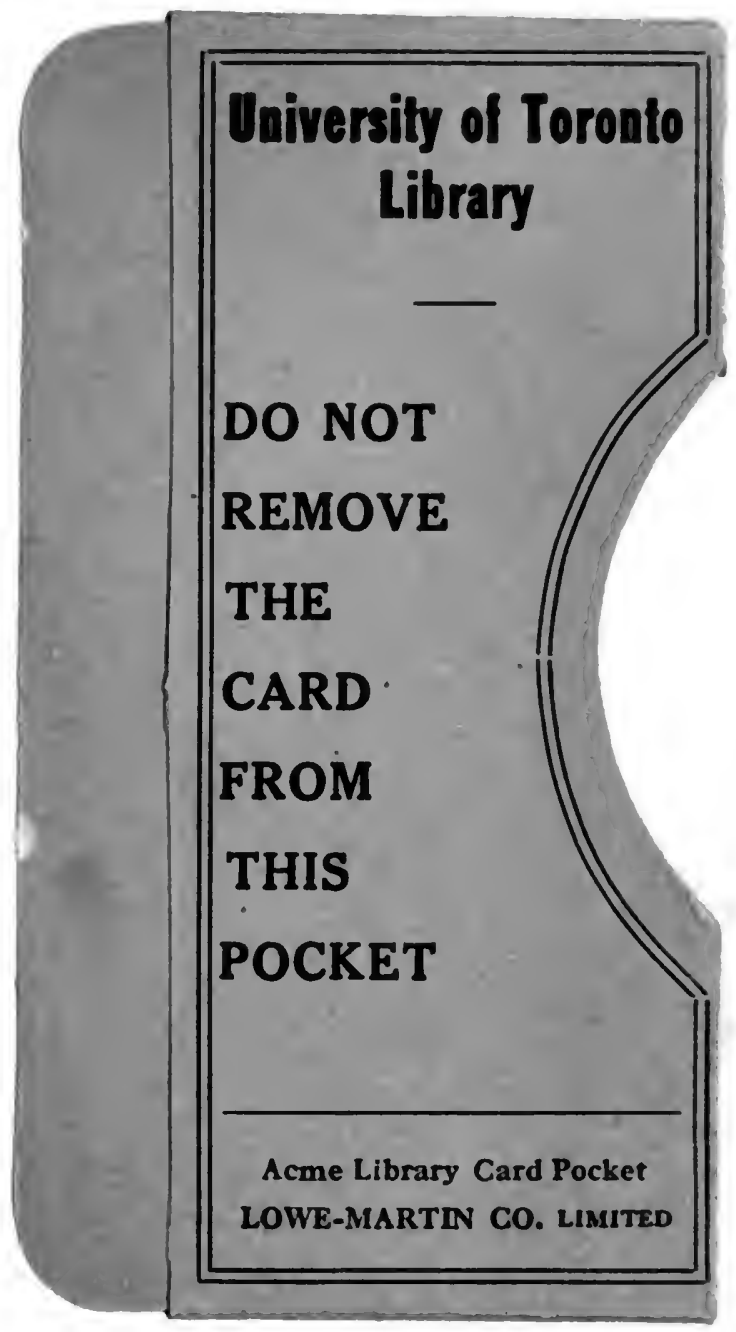


